\title{
CKß8-1 alters expression of cyclin E in colony forming units-granulocyte macrophage (CFU-GM) lineage from human cord blood CD $34^{+}$cells
}

\author{
Eui-Kyu Noh ${ }^{1}$, Jae-Sun $\mathrm{Ra}^{1}$, Seong-Ae Lee ${ }^{1}$, \\ Byoung S. Kwon ${ }^{1}$ and In-Seob Han ${ }^{1,2}$ \\ ${ }^{1}$ Immunomodulation Research Center \\ Department of Biological Science \\ University of Ulsan \\ Ulsan 680-749, Korea \\ ${ }^{2}$ Corresponding author: Tel, 82-52-259-2352; \\ Fax, 82-52-259-1694; E-mail, hanis@ulsan.ac.kr
}

Accepted 12 October 2005

Abbreviations: BFU-E, burst forming unit-erythroid; $\mathrm{CB}$, cord blood; CFU-GEMM, colony forming unit-granulocyte/erythrocyte/macrophage/megakaryocyte; CFU-GM, colony forming units-granulocyte/macorphage; EPO, erythropoietin; IMDM, Isscove's modified Dulbecco's medium

\begin{abstract}
A C6 $\beta$-chemokine, CK $\beta 8-1$, suppressed the colony formation of CD34 ${ }^{+}$cells of human cord blood (CB). Molecular mechanisms involved in CKB8-1-medicated suppression of colony formation of $\mathrm{CD} 34^{+}$cells are not known. To address this issue, the level of various $\mathrm{G} 1 / \mathrm{S}$ cell cycle regulating proteins in CKB8-1-treated CD34 ${ }^{+}$cells were compared with those in untreated $\mathrm{CD} 34^{+}$cells. CK $\beta 8-1$ did not significantly alter the expression of the G1/S cycle regulation proteins (cyclin D1, D3, and E), CDK in hibitor (p27and $\mathrm{Rb}$ ), and other cell proliferation regulation protein ( $p 53$ ) in CB CD $34^{+}$cells. Here we describe an in vitro system in which $\mathrm{CB}$ CD $34^{+}$cells were committed to a multipotent progenitor lineage of colony forming units-granulocyte/macrophage (CFU-GM) by a simple combination of recombinant human (rh) GM-CSF and rhIL-3. In this culture system, we found that cyclin $E$ protein appeared later and disappeared faster in the CKB8-1-treated cells than in the control cells during CFU-GM lineage development. These findings suggested that cyclin $\mathrm{E}$ may play a role in suppressing the colony formation of CFU-GM by CK $\beta 8-1$.
\end{abstract}

Keywords: cell cycle; chemokine; cyclin E; gran- ulocytes; macrophages; multi potent; stem cells

\section{Introduction}

Hematopoietic stem cells (HSC) can differentiate into different lineages, including myeloid, megakaryocyte, lymphoid, and erythroid cells. Key issue in HSC biology has focused on how their commitment to a particular lineage and maturation is regulated at the cellular and molecular levels. Because HSC have been widely used in the treatment of leukemia (Miyamoto et al., 2000) and are present in high frequency in umbilical cord blood (CB), human $C B$ has been established as a source of hematopoietic repopulating cells (Broxmeyer and Smith, 1999; Gluckman, 2001; Kim et al., 2003; Chung et al., 2005). This issue is of great clinical relevance. During hematopoiesis, cytokines act as developmental signals that direct the commitment of progenitor cells into and through particular lineages.

It is of interest that all C6 $\beta$-chemokines so far analyzed, including CK $\beta 8-1$, have shown myelosuppressive activity on colony forming unit-granulocyte/ macrophage (CFU-GM), burst forming unit-erythroid (BFU-E), and colony forming unit-granulocyte/erythrocyte/macrophage/megakaryocyte (CFU-GEMM). Most non-C6 $\beta$-chemokines do not have such suppressive activity. Although it is unknown what mechanism of CK $\beta 8-1$ inhibits proliferation of myeloid progenitor cells, the properties of myelosuppression can be used in a human chemotherapy setting. Lkn-1, a member of human C6 $\beta$-chemokine, protected bone marrow myeloid progenitor cells when cytotoxic chemotherapeutics were used in a preclinical experiment (Kim et al., 2003). This may be due to the role of Lkn-1 in decreasing the number of myeloid progenitor cells that enter $S$ phase of the cell cycle. Inhibition of human endothelial cell proliferation by a CXC chemokine, PF4, is associated with a decrease in cyclin E-cyclin dependent kinase 2 (CDK2) activity (Gentilini et al., 1999). PF4 is known as an inhibitor of hematopoeitic progenitor cell proliferation (Han et al., 1990; Broxmeyer et al., 1993). As cells progress through the G1-phase, cyclin $E$ is synthesized with a peak in late $G 1$. Cyclin $E$ associates with CDK2 and is essential for entry into the S phase (Ohtsubo et al., 1995). Once cells enter 
the $S$ phase, cyclin $E$ is degraded and CDK2 then associates the cyclin A (Fotedar and Fotedar, 1995).

In this study we sought to further understand the inhibitory effect of CK $38-1$ on colony formation of $\mathrm{CD}_{3}{ }^{+}$cells from human $\mathrm{CB}$. As such, we examined whether CK $\beta 8-1$ played a role in regulating expression of cell-cycle related proteins in order to arrest the commitment to cell lineage, especially to CFU-GM.

\section{Materials and Methods}

\section{Cells and cell culture}

$C B$ cells were obtained from normal human $C B$ scheduled for discard after delivery. A CD $34^{+}$cellenriched fraction was prepared by density cut separation on Ficoll-Hypaque gradients (1.070 $\mathrm{g} / \mathrm{cm}^{3}$ ). A MACS kit (Miltenyi Biotech, Germany) was used to isolate the $\mathrm{CD} 34^{+}$cells from the cell suspension (Kim, 2003). CD34 ${ }^{+}$cells were incubated in Iscove's modified Dulbecco's medium (IMDM) supplemented with 30\% fetal bovine serum (Gibco-Life), 1\% BSA (Gibco), 0.1 mM 2-mercaptoethanol (Sigma), and $2 \mathrm{mM}$ L-glutamine (Sigma) with either recombinant human GM-CSF (rhGMCSF $50 \mathrm{ng} / \mathrm{ml}$; Stem Cell Technologies, Vancouver, Canada), and rhlL-3 (10 ng/ml; Stem Cell Technologies) for CFU-GM differentiation, or rhEPO (1 $\mathrm{U} / \mathrm{ml}$; Stem Cell Technologies) for erythroid differentiation. Cells were plated in $35-\mathrm{mm}$ culture dishes.

\section{Colony forming assay}

To monitor the clonogenic growth of differentiated cell lineages, cells were plated in triplicate and incubated in IMDM at $37^{\circ} \mathrm{C}$ under $5 \% \mathrm{CO}_{2}$. Colonies were counted under an inverted microscope as previously described (Han et al., 2003).

\section{Western blot analysis}

Protein samples were boiled in a $1 \times$ SDS-sample loading buffer $(50 \mathrm{mM}$ Tris- $\mathrm{HCl} \mathrm{pH} 6.8,10 \%$ glycerol, $1 \%$ SDS, $0.02 \%$ bromphenol blue, and $5 \% \beta$-mercaptoethanol), fractionated by $12 \%$ SDS-PAGE, and electroblotted (10 mM CAPS, 10\% methanol, $\mathrm{pH} 11$ ) onto a nitrocellulose membrane. After blocking the nonspecific binding (blocking buffer; $20 \mathrm{mM}$ Tris, $\mathrm{pH}$ $7.8,145 \mathrm{mM} \mathrm{NaCl}, 0.1 \%$ Tween-20, 3\% nonfat dried milk), the membrane was incubated with different antisera (cyclin A, cyclin D1, cyclin D3, cyclin E, p27, $\mathrm{p} 53$, and $\beta$-actin). The immunoblot was detected by ECL techniques (Amersham Phamacia Biotech).

\section{Results and Discussion}

\section{CKß8-1 did not alter G1 cell cycle protein expression}

Chemokines have a biological activity to inhibit proliferation of hematopoietic progenitor cells. Although previous studies have reported that several chemokines suppressed the proliferation of progenitor cells, the underlying molecular mechanisms of these chemokines still remain to be established (Broxmeyer et al., 1997; Su et al., 1997; Crow et al., 2001; Han et al., 2003). We also reported that chemokine CK $\beta 8-1$ and Lkn-1 suppressed the proliferation of myeloid progenitor cells from human CB (Han et al., 2003; Kim et al., 2003) without clarification of functional mechanism of suppression by them.

To investigate whether CK $\beta 8$-1 was effective in the regulation of a cell cycle for its suppression activity, we monitored the expression of cell cycle regulating proteins. As shown in Figure 1, we did not observe any significant activity of CK $\beta 8-1$ on the expression of the G1/S cycle regulating proteins (cyclin D1, D3, and $\mathrm{E}$ ), CDK inhibitors, p27and $\mathrm{Rb}$, and other cell proliferation regulating protein, p53 in CB CD34 cells. The cyclin D1 protein that was absent in the freshly harvested myeloid progenitor cells, appeared and was maintained during a 5 days culture. The cyclin D3 protein was very low at all stages of the culture. It is likely that cyclin D1 plays an important role rather than cyclin D3 in colony formation of

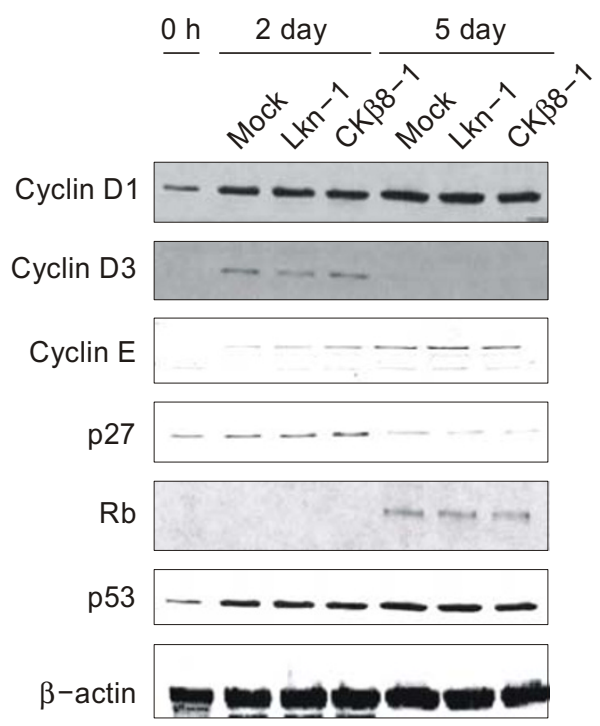

Figure 1. Immunoblotting detection of cell cycle related proteins in myeloid progenitor cells of human $\mathrm{CB}$. CD34 ${ }^{+}$cells from human $\mathrm{CB}$ were allowed to myeloid lineage culture in the absence or presence of CK $\beta 8-1$ or Lkn-1. About $50 \mu \mathrm{g}$ protein were separated by SDS-PAGE, transferred to a nitrocellulose membrane, and incubated with the antibodies to the indicated proteins. 
myeloid progenitor cells from human CB CD34 ${ }^{+}$ cells. A previous study has indicated that the action of IFN- $\gamma$ to reduce CFU-GM and BFU-E colony formation from $\mathrm{CD} 34^{+}$cells may be linked to effects on the cell cycle (Selleri et al., 1996). Recently, Lkn-1 affected cell cycle the signal progression by cyclin D3 induction (Kim et al., 2003). We showed that cyclin $\mathrm{E}$ protein appeared at day 5 , whereas p27 protein was down-regulated in these cells. $\mathrm{Re}$ garding the role of $\mathrm{p} 27$ protein, it should be noted that p27 protein is an inhibitory protein specific to cyclin $\mathrm{E}$ in $\mathrm{CB}$ hematopoietic cell cycle progression. In this set of experiments, the p53 protein was up-regulated at day 2 and day 5 compared to cells at day 0 . Signaling pathway involving p53 is the main pathway utilized by $\mathrm{CD} 34^{+}$cells to arrest cell cycle progression at multiple checkpoints to halt proliferation (Tao et al., 2003). These results together can be explained by two different hypotheses; one is that heterogeneous myeloid progenitor cell population may not be arrested by a single mechanism during cell cycle, the other is that cell cycle is not involved in myelosuppresive action of CK $38-1$ on human $\mathrm{CB} \mathrm{CD}_{34}^{+}$cells. To further investigate the inhibitory mechanism of CK $\beta 8-1$, we focused on

Table 1. Differential lineages from human $\mathrm{CB} C D 34^{+}$cells stimulated by different combinations of growth factors.

\begin{tabular}{lccc}
\hline \multicolumn{1}{c}{ Growth factors } & BFU-E & CFU-GM & CFU-GEMM \\
\hline rhEPO $(1 \mathrm{U} / \mathrm{ml})$ & $77 \%$ & $23 \%$ & $0 \%$ \\
$\begin{array}{l}\text { rhGM-CSF }(50 \mathrm{ng} / \mathrm{ml}) \\
+ \text { rhlL-3 }(10 \mathrm{ng} / \mathrm{ml})\end{array}$ & $0 \%$ & $100 \%$ & $0 \%$ \\
\hline
\end{tabular}

CFU-GM cells from human CB CD34 ${ }^{+}$cells because of the importance of CFU-GM for granulocyte recovery in bone marrow transplantations (Jansen et al., 2002).

\section{CFU-GM colonies were formed from human CB CD34 ${ }^{+}$cells}

Using colony assay, we monitored the lineage commitment of $\mathrm{CD}_{3}{ }^{+}$cells from human $\mathrm{CB}$ after treatment with either a combination of GM-CSF (500 $\mathrm{ng} / \mathrm{ml}) / \mathrm{lL}-3(10 \mathrm{ng} / \mathrm{ml})$ or EPO $(1 \mathrm{U} / \mathrm{ml})$ alone. In Table 1, only CFU-GM colonies formed in the presence of GM-CSF/IL-3, whereas EPO alone could obtain up to $77 \%$ of BFU-E after 7 days culture with.

\section{Cyclin E expression was delayed in CFU-GM cells by CKß8-1}

To investigate the underlying mechanism of CKB8-1 on CFU-GM cells, we cultured $\mathrm{CD}_{3} 4^{+}$cells from human $\mathrm{CB}$ in the media containing GM-CSF/IL-3. We analyzed the expression of cyclin $E$, which is essential for entry into the $S$ phase in human cells (Ohtsubo et al., 1995), and its inhibitory protein, p27 by immunoblot analysis. In Figure 2, the level of cyclin $\mathrm{E}$ increased within $24 \mathrm{~h}$ in control cells, whereas cyclin $E$ protein appeared in CK $\beta 8-1$ - treated cells after $24 \mathrm{~h}$ culture. It suggested that CK $\beta 8-1$ delays the expression of cyclin E in CFU- GM cells and consequently prevents normal entry of cells into the $S$ phase. It is of note that the level of cyclin $E$ was maintained at high level until day 9 but begun to decrease on day 11. However, when cells were treated with $\mathrm{CK} \beta 8-1$, cyclin $\mathrm{E}$ protein completely disappeared before day 11. Colony formation had
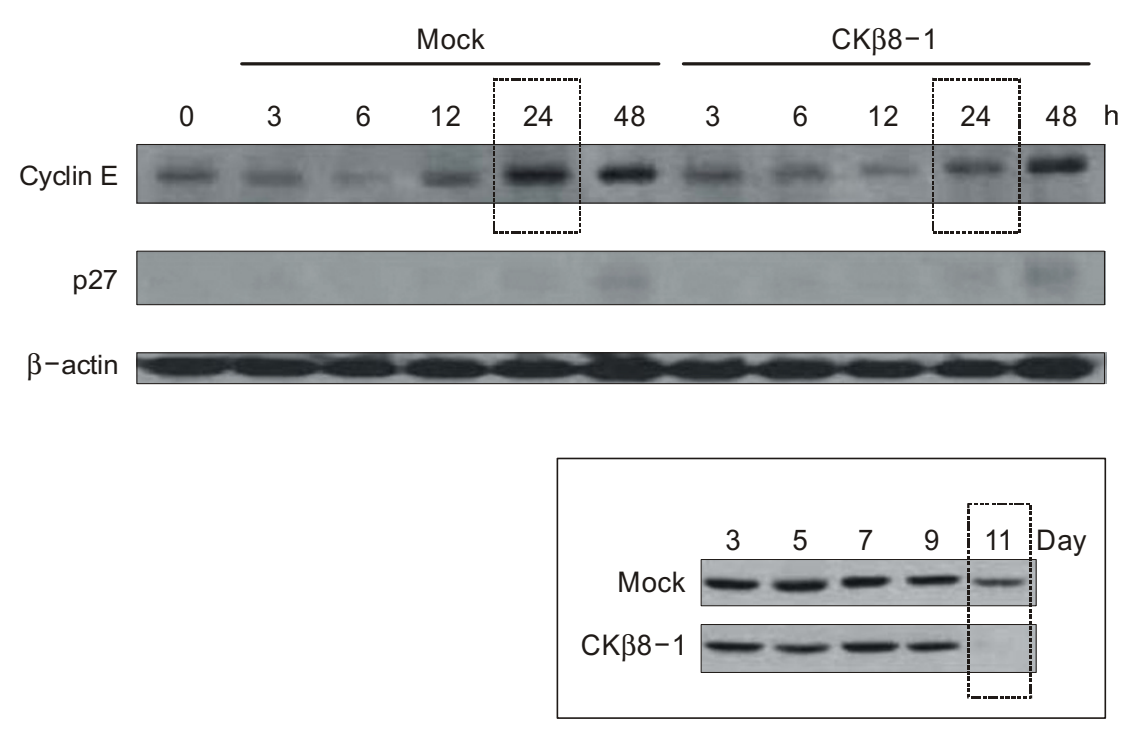

Figure 2. Immunoblotting detection of cyclin $D$, $E$, in CFU-GM lineage from human CB. $\mathrm{CD} 34^{+}$cells from human $\mathrm{CB}$ were allowed to committee to CFU-GM lineage culture in the absence or presence of CK $\beta 8-1$. 
been observed from approximately day 5 to day 11 in specific HSC colony culture media, suggesting that the proliferation rate of hematopoietic progenitor cells may be highly activated during this culture period. Recent work showed that cyclin A2 gene was moderately expressed, while cyclin $D$ expression was very low in human $\mathrm{CD} 34^{+}$cells under normal growth conditions (Tao et al., 2003). However, our results did not show any significant difference in the level of cyclin A and D in CKB8-1 treated cells (data not shown). Alternatively, we have shown that cyclin $E$ was up-regulated in proliferating human $C B$ CFU-GM cells, suggesting that cyline $\mathrm{E}$ may be crucial in determining S-phase transition of the CFUGM cells. A human chemokine, PF4, suppressed colony formation of myeloid progenitor cells by interference with the cell cycle machinery (Gentilini et al., 1999). PF4 treatment caused a decrease in cyclin E-CDK2 activity. This supported the notion that cyclin $E$ may be a target molecule of CK $38-1$ in preventing colony formation of CFU-GM. Among the most important mammalian cyclin-CDK complexes known so far, cyclin $E$ is synthesized with a peak late in G1-phase (Boonstra, 2003). Another study has reported that cyclin $E$ had a major role in the control of the G1- and S-phase transitions of hematopoietic cells (Mazumder et al., 2004). In addition, the expression of cyclin $E$ was enhanced during Notch-induced self-renewal of murine HSCs (Satoh et al., 2004). The behavior of cell cycle control genes during hematopoietic differentiation was classified into four patterns and cyclin $E$ placed in the group having no induction or stable expression (Furukawa, 2002). Therefore, it appeared that CK $\beta 8-1$ breaks the stable expression of cyclin $E$ and consequently prevents proliferation of CFU-GM. However, it is not known that these cell cycle arrested cells in the late G1 phase by a down-regulation of cyclin $E$ goes through apoptotic cell death. The present study has shown that CKB8-1 inhibits proliferation of CFU-GM from human $\mathrm{CB} C D 34^{+}$cells by regulating expression of cyclin $E$, which is involved in the cytokinemediated cell cycle commitment.

\section{Acknowledgement}

This work was supported by the SRC fund to the IRC at the University of Ulsan from KOSEF and the Ministry of Science and Technology in Korea.

\section{References}

Boonstra J. Progression through the G1-phase of the ongoing cell cycle. J Cell Biochem 2003;90:244-52

Broxmeyer HE, Sherry B, Cooper S, Lu L, Maze R, Beckmann MP, Cerami A, Ralph P. Comparative analysis of the human macrophage inflammatory protein family of cytokines (chemokines) on proliferation of human myeloid progenitor cells. Interacting effects involving suppression, synergistic suppression, and blocking of suppression. J Immunol 1993; 150:3448-58

Broxmeyer HE, Mantel CR, Aronica SM. Biology and mechanisms of action of synergistically stimulated myeloid progenitor cell proliferation and suppression by chemokines. Stem Cells 1997;15 Suppl 1:69-77; discussion 78

Broxmeyer HE, Smith FO. Cord blood stem cell transplantation. In Stem Cell Transplantation (BK Forman SI, Thomas ED, eds). 1999, 431-443, Blackwell Scientific Publications, Cambridge

Chung JW, Kim GY, Mun YC, Ahn JY, Seong CM, Kim JH. Leukotriene B4 pathway regulates the fate of the hematopoietic stem cells. Exp Mol Med 2005;37:45-50

Crow M, Taub DD, Cooper S, Broxmeyer HE, Sarris AH. Human recombinant interferon-inducible protein-10: intact disulfide bridges are not required for inhibition of hematopoietic progenitors and chemotaxis of $\mathrm{T}$ lymphocytes and monocytes. J Hematother Stem Cell Res 2001;10:147-56

Fotedar R, Fotedar A. Cell cycle control of DNA replication. Prog Cell Cycle Res 1995;1:73-89

Furukawa Y. Cell cycle control genes and hematopoietic cell differentiation. Leuk Lymphoma 2002;43:225-31

Gentilini G, Kirschbaum NE, Augustine JA, Aster RH, Visentin GP. Inhibition of human umbilical vein endothelial cell proliferation by the CXC chemokine, platelet factor 4 (PF4), is associated with impaired downregulation of p21 (Cip1/ WAF1). Blood 1999;93:25-33

Gluckman E. Hematopoietic stem-cell transplants using umbilical-cord blood. N Engl J Med 2001;344:1860-1

Han IS, Ra JS, Kim MW, Lee EA, Jun HY, Park SK, Kwon BS. Differentiation of CD34+ cells from human cord blood and murine bone marrow is suppressed by $\mathrm{C} 6$ betachemokines. Mol Cells 2003;15:176-80

Han ZC, Sensebe L, Abgrall JF, Briere J. Platelet factor 4 inhibits human megakaryocytopoiesis in vitro. Blood 1990; 75:1234-9

Jansen J, Thompson JM, Dugan MJ, Nolan P, Wiemann MC, Birhiray R, Henslee-Downey PJ, Akard LP. Peripheral blood progenitor cell transplantation. Ther Apher 2002;6:5-14

Kim HL. Comparison of oligonucleotide-microarray and serial analysis of gene expression (SAGE) in transcript profiling analysis of megakaryocytes derived from CD34+ cells. Exp Mol Med 2003;35:460-6

Kim HS, Lim JB, Min YH, Lee ST, Lyu CJ, Kim ES, Kim HO. Ex vivo expansion of human umbilical cord blood CD34+ cells in a collagen bead-containing 3-dimensional culture system. Int J Hematol 2003;78:126-32

Kim IS, Ryang YS, Kim YS, Jang SW, Sung HJ, Lee YH, Kim J, Na DS, Ko J Leukotactin-1-induced ERK activation is mediated via $\mathrm{Gi} / \mathrm{Go}$ protein/PLC/PKC delta/Ras cascades in HOS cells. Life Sci 2003;73:447-59

Kim WY, Broxmeyer HE, Han IS, Park DH, Lee KM, Vinay 
DS, Kwon BS. Effect of leukotactin-1 on the protection in vivo of myeloid progenitor cells against cytotoxic chemotherapeutics. J Hematother Stem Cell Res 2003;12:107-13

Mazumder S, DuPree EL, Almasan A. A dual role of cyclin E in cell proliferation and apoptosis may provide a target for cancer therapy. Curr Cancer Drug Targets 2004;4:65-75

Miyamoto T, Weissman IL, Akashi K. AML1/ETO-expressing nonleukemic stem cells in acute myelogenous leukemia with 8;21 chromosomal translocation. Proc Natl Acad Sci U S A 2000;97:7521-6

Ohtsubo M, Theodoras AM, Schumacher J, Roberts JM, Pagano M. Human cyclin E, a nuclear protein essential for the G1-to-S phase transition. Mol Cell Biol 1995;15:2612-24

Satoh Y, Matsumura I, Tanaka H, Ezoe S, Sugahara H, Mizuki M, Shibayama H, Ishiko E, Ishiko J, Nakajima K,
Kanakura Y. Roles for c-Myc in self-renewal of hematopoietic stem cells. J Biol Chem 2004;279:24986-93

Selleri C, Maciejewski JP, Sato T, Young NS. Interferongamma constitutively expressed in the stromal microenvironment of human marrow cultures mediates potent hematopoietic inhibition. Blood 1996;87:4149-57

Su S, Mukaida N, Wang J, Zhang Y, Takami A, Nakao S, Matsushima K. Inhibition of immature erythroid progenitor cell proliferation by macrophage inflammatory protein-1alpha by interacting mainly with a C-C chemokine receptor, CCR1. Blood 1997;90:605-11

Tao W, Hangoc G, Hawes JW, Si Y, Cooper S, Broxmeyer $\mathrm{HE}$. Profiling of differentially expressed apoptosis-related genes by cDNA arrays in human cord blood CD34+ cells treated with etoposide. Exp Hematol 2003;31:251-60 